\title{
Picloram, fertilizer, and defoliation interactions on spotted knapweed reinvasion
}

\author{
JAMES S. JACOBS, ROGER L. SHELEY, AND JOELLA R. CARTER
}

Authors are post-doctoral research associate; associate assistant professor; and graduate research assistant, Department of Land Resources and Environmental Sciences, Montana State University, Mont. 59717.

\section{Abstract}

Spotted knapweed (Centaurea maculosa Lam.) management may be enhanced by integrating strategies that stimulate and maintain competitive grasses. The objective of this study was to determine if picloram, fertilizer, and timing and frequency of grass defoliation could be integrated to minimize spotted knapweed reinvasion. Sixteen chemical treatments [4 picloram rates $\left(0.00,0.14,0.28\right.$, and $0.42 \mathrm{~kg}$ a.i. $\left.\mathrm{ha}^{-1}\right)$ and 4 fertilizer rates (source: 16-20-0, N-P-K; material: $0.0,66,132,198 \mathrm{~kg} \mathrm{ha}^{-1}$ )] were applied in the spring of 1994 to 4 by $4 \mathrm{~m}$ plots and factorially arranged in a randomized-complete-block design. Within each plot, 6 grass defoliation treatments were randomly applied to 1 by $1 \mathrm{~m}$ sub-plots. From 1994 through 1997, 60\% of the above ground grass biomass was hand clipped and removed from the plots during the spring, summer, fall, alternating spring/fall, all 3 seasons. A control received no grass defoliation. The experiment was replicated 4 times at 2 sites dominated by spotted knapweed. At peak standing crop in 1997 spotted knapweed density, grass and spotted knapweed biomass; and percent cover of spotted knapweed, grass, litter, and bare ground were measured. Data were analyzed as a split-plot using analysis of variance. Four years after treatment all rates of picloram reduced spotted knapweed density, biomass, and cover, and increased grass yield. Nitrogen and $P$ fertilizer tended to increase spotted knapweed density and biomass. Nitrogen and $P$ fertilizer plus defoliation in all 3 seasons caused a greater increase in spotted knapweed reinvasion at the site with Kentucky bluegrass (Poa pratensis $L$.) than the site with timothy (Phleum pratense L.) and smooth brome (Bromus inermis Leys.). Fall-only defoliation and no defoliation appear to deter spotted knapweed reinvasion better than defoliation in all 3 seasons and alternately in the spring and fall.

Key Words: Centaurea maculosa, integrated weed management, grass defoliation, grazing management

Spotted knapweed (Centaurea maculosa Lam.), a short-lived perennial native to Eurasia, is rapidly invading rangeland throughout western North America. This aggressive weed has been spreading at about $27 \%$ per year and infests over 2.8 million hectares in Montana, and adjoining states and Canadian provinces (Chicoine et al. 1985, Lacey et al. 1989). Spotted knapweed can be found in 326 counties in the western United States (Sheley et al. 1998). Impacts associated with this species include reduced forage production (Watson and Renney 1974), plant species

\footnotetext{
Manuscript accepted 6 Sept. 1999.
}

Resumen

El manejo de "Spotted knapweed"(Centaurea maculosa Lam.) puede ser mejorado mediante la integración de estrategias que estimulan y mantienen los zacates competitivos. El objetivo de este estudio fue determinar si el picloram, la fertilización y la época y frecuencia de defoliación del zacate pudieran ser integrados para minimizar la reinvasión de "Spotted knapweed". En primavera de 1994 se aplicaron 16 tratamientos químicos [4 dosis de picloram $\left(0.00,0.14,0.28\right.$ y $\left.0.42 \mathrm{~kg}^{\text {i.a }} \mathrm{ha}^{-1}\right)$ y 4 dosis de fertilizante(0.0, 66, 132 y $198 \mathrm{~kg} \mathrm{ha}^{-1}$; fuente: 16-20-0, N-P-K)] en parcelas de $4 \times 4 \mathrm{~m}$ bajo un diseño de bloques completos al azar en arreglo factorial. Dentro de cada parcela se aplicaron 6 tratamientos de defoliación, los cuales se asignaron aleatoriamente a subparcelas de 1 x $1 \mathrm{~m}$. De 1994 a 1997, durante las épocas de primavera, verano, otoño, alternadamente en primavera/verano y en las tres estaciones del año, se corto y removió manualmente el $60 \%$ de la biomasa aérea de las parcelas. Las parcelas control no recibieron defoliación del zacate. El experimento se repitió 4 veces en 2 sitios en los que predominaba el "Spotted knapweed". En 1997, cuando se alcanzo la máxima producción de biomasa en pie, se midió la densidad de "Spotted knapweed", la biomasas de los zacates y del "Spotted knapweed", y el porcentaje de cobertura de "Spotted knapweed, zacates, mantillo y suelo desnudo. Los datos se analizaron mediante análisis de varianza y bajo el diseño experimental de parcelas divididas. Cuatro años después de aplicar los tratamientos, todas las dosis de picloram redujeron la densidad, biomasa y cobertura de "Spotted knapweed" e incrementaron el rendimiento de forraje de los zacates. La fertilización nitrogenada y fosforada tendieron a incrementar la densidad y biomasa de "Spotted Knapweed". La fertilización nitrogenada y fosforada mas la defoliación en las tres estaciones causo una mayor reinvasión de "Spotted knapweed" en el sitio con "Kentucky bluegrass" (Poa pratensis L.) que en el sitio con "Timothy (Phleum pratense L.) y "Smooth brome" (Bromus inermis Leys.). Defoliar solo en otoño y el no defoliar parece detener la reinvasión de "Spotted knapweed" mejor que la defoliación en todas las tres estaciones y alternativamente en primavera y otoño.

diversity (Tyser and Key 1988), wildlife habitat (Bedunah and Carpenter 1989) and increased bare ground, surface water runfoff and stream sedimentation (Lacey et al. 1989), and management costs (Griffith and Lacey 1989).

Most broadleaf herbicides are effective in reducing spotted knapweed populations. Picloram (4-amino-3,5,6-trichloropicolinic acid) applied at a rate of $0.28 \mathrm{~kg}$ active ingredient (a.i.) $\mathrm{ha}^{-1}$ provides control for 2 to 5 years (Davis 1990). Although the per- 
sistence of picloram in the soil affects weeds for 12 to 30 months (Hamaker et al. 1967), extended control is enhanced by competition from residual perennial grasses that are released by the herbicide application (Sheley et al. 1998). Combining herbicide and fertilizer applications has increased forage production on rangelands (Hart et al. 1995); however, little is known about combining them to control knapweed and enhance forage production.

Intergrating picloram and fertilizers may have a synergistic effect on providing spotted knapweed control and enhanced grass production. In a pilot study, Sheley and Roché (1982) combined picloram $(0.28 \mathrm{~kg}$ a.i. ha $\left.^{-1}\right)$ and fertilizer $(\mathrm{N}+\mathrm{P}: 17.9+22.4$ $\mathrm{kg} \mathrm{ha}^{-1}$ ) which increased grass yield from 275 (control) and 660 (picloram alone) to 2,200 (picloram plus fertilizer) $\mathrm{kg} \mathrm{ha}^{-1}, 2$ years after application. In that study, knapweed control was also greater where picloram was combined with fertilization than the control and picloram alone. More recently, Sheley and Jacobs (1997) found no picloram by $\mathrm{N}+\mathrm{P}$ fertilizer interactions in Montana. Picloram treatments $(0.14$ to $0.42 \mathrm{~kg}$ a.i. $\mathrm{ha}^{-1}$ ) reduced spotted knapweed to nearly zero, and fertilization at the highest rate (180 $\left.\mathrm{kg} \mathrm{ha}^{-1} ; 16-20-0 \mathrm{NPK}\right)$ increased grass yield on the site with a substantial grass understory.

Spotted knapweed seeds can remain dormant in the soil for up to 8 years and reinvasion on sites treated with picloram usually begins within 2-5 years after herbicide application (Davis et al. 1993). While many factors affect picloram persistence in the soil including photodegredation, precipitation, and soil texture (Davis 1990), and therefore longevity of spotted knapweed control, it is believed that the competitive ability of the residual grass on treated sites also affects spotted knapweed reinvasion (Sheley et al. 1998). The competitive interaction between weeds and perennial grasses is affected by frequency, timing and intensity of defoliation which in turn affects the ability of perennial grass communities to withstand weed invasion (Maschinski and Whithan 1989, Jacobs and Sheley 1997). Although studies suggest that moderate grazing does not accelerate invasion of knapweeds (Centaurea spp.) into rangeland (Sheley et al. 1997, Jacobs and Sheley 1997), we found no studies that attempt to quantify the effects of defoliation on their reinvasion after control.

An important concern of rangeland managers is how to prevent or reduce weed reinvasion on areas where weeds have been controlled. The overall objective of this study was to determine the effect of the timing and frequency of grass defoliation on spotted knapweed reinvasion on areas treated with picloram and fertilizer combinations. Specific objectives were to 1 ) determine if picloram and fertilizer interact to increase long-term spotted knapweed control or grass yield, and 2) determine if timing and frequency of grass defoliation affected spotted knapweed reinvasion. We hypothesized that picloram and fertilizer would interact to increase spotted knapweed control and grass yield, which would limit reinvasion. In addition, we believe that spotted knapweed reestablishment would be greater in areas with more frequent grass defoliation and defoliation in the spring than summer and fall defoliations.

\section{Materials and Methods}

\section{Study Sites}

Field studies were conducted from 1994 through 1997 on 2 sites located $15 \mathrm{~km}$

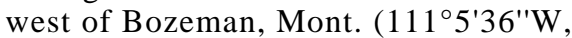
$\left.45^{\circ} 35^{\prime} 26^{\prime \prime} \mathrm{N}\right)$. Both sites were within a Festuca idahoensis/Agropyron spicatum habitat type (Mueggler and Stewart 1980), and dominated by spotted knapweed. Site 1 was an abandoned hayfield. Spotted knapweed densities were $470 \pm 140$ plants $\mathrm{m}^{-2}$. Associated grass species were smooth bromegrass (Bromus inermis Leys), timothy (Phleum pratense L.), and Kentucky bluegrass (Poa pratensis L.). Associated grass on site 2 was predominantly Kentucky bluegrass. Spotted knapweed density was $140 \pm 107$ plants $\mathrm{m}^{-2}$. Soils at both sites consisted of $70 \%$ Beaverton cobbly loam (loamy-skeletal over sandy or sandy-skeletal mixed, Typic Argiborolls) and 30\% Hyalite loam (fine-loamy, mixed, Typic Argiborolls). Sites were nearly level and at an elevation of $1,340 \mathrm{~m}$. Annual precipitation ranges from 380 to $480 \mathrm{~mm}$ and the frost-free period ranges from 90 to 110 days at both sites.

\section{Experimental Design}

Sixteen chemical treatments (4 picloram rates, 4 fertilizer rates) were applied to 4 by $4 \mathrm{~m}$ plots and factorially arranged in a randomized-complete-block design. Within each plot, 6 different defoliation treatments were randomly applied to $1 \times 1$ $\mathrm{m}$ sub-plots. The experiment was replicated 4 times at both sites.

Picloram rates of $0.0,0.14,0.28$, and $0.42 \mathrm{~kg}$ a.i. ha $^{-1}$ were applied using a 6 nozzle backpack sprayer delivering 130 liters $\mathrm{ha}^{-1}$ spray solution. Granular fertilizer was broadcast at $\mathrm{N}+\mathrm{P}$ rates of $0.0+0.0,10.5+$ $13.2,21.1+26.4$, and $31.7+39.6 \mathrm{~kg} \mathrm{ha}^{-1}$ (source: 16-20-0, N-P-K; material: 0.0, 66, $132,198 \mathrm{~kg} \mathrm{ha}^{-1}$ ) using a hand-cyclone applicator. Both sites were treated on 2 May 1994 when spotted knapweed was in the rosette stage. Air temperature, soil temperature (surface), and relative humidty were $17.5^{\circ} \mathrm{C}, 21^{\circ} \mathrm{C}$, and $90 \%$, respectively, at the time of application. Winds ranged from 0 to $6 \mathrm{~km} \mathrm{hr}^{-1}$. Individual $4 \mathrm{x} 4 \mathrm{~m}$ plots were spatially separated from each other by a $2.1 \mathrm{~m}$ buffer zone treated with $0.28 \mathrm{k}$ a.i. ha ${ }^{-1}$ of picloram to prevent spotted knapweed seed contamination from neighboring plots.

From fall 1994 through fall 1997, six defoliation regimes differing in the frequency and timing of defoliation were applied as 1 x $1 \mathrm{~m}$ sub-plots. They were control (no defoliation), spring, mid-summer, fall, alternating spring/fall, and repeated defoliations in spring, summer, and fall. Defoliation treatments were applied by hand-clipping grasses to $60 \%$ of the above-ground biomass. Defoliation level was calibrated by clipping grass from ten, $0.2 \times 0.5 \mathrm{~m}$ plots estimated at $60 \%$ and comparing their average weight with the average weight of grass clipped to the soil surface from ten, $0.2 \times 0.5 \mathrm{~m}$ plots. All clippings were removed from the plots. Repeated defoliations removed $60 \%$ of the remaining foliage including all regrowth.

\section{Sampling}

At peak standing crop (August), aboveground biomass within 1 randomly located $0.5 \mathrm{~m}^{2}$ hoop was harvested from each subplot in 1997. Grass and spotted knapweed were separated and dried at $60^{\circ} \mathrm{C}$ until weights were constant ( $48 \mathrm{hrs}$ minimum) and then weighed. Juvenile (plants without flower stems) and total spotted knapweed density (plants $\mathrm{m}^{-2}$ ) were counted within randomly located $0.2 \times 0.5 \mathrm{~m}$ frames in each sub-plot prior to biomass harvest. Within the same frame visual estimations of percent cover were estimated for spotted knapweed, all grass species, litter, and bare ground.

\section{Data Analysis}

Sites were analyzed separately. Data were analyzed as a split-plot using analysis of variance (SAS Institute, Inc. 1990). Picloram and fertilizer were applied as whole-plots. Defoliation was applied as sub-plots. Picloram, fertilizer, and their interaction were tested using block* picloram*fertilizer as the error term. Defoliation, picloram*defoliation, fertilizer*defoliation, and the 3-way interaction were tested using the residual error. When significant $(\mathrm{P}<$ 
$0.05)$ F-test were calculated, diferences among means were tested using protected least significant differences procedures (Peterson 1985).

\section{Results}

\section{Density}

Juvenile $(p<0.001)$ and total spotted knapweed $(\mathrm{p}<0.001)$ density were affected by picloram 4 years after treatment at site 1 . All picloram rates reduced juvenile and total spotted knapweed density below that of the control. Juvenile density was reduced from 144 plants $\mathrm{m}^{-2}\left(0.0 \mathrm{~kg}\right.$ a.i. $\mathrm{ha}^{-1}$ picloram) to 33,6 , and 1 plants $\mathrm{m}^{-2}(0.14$, $0.28,0.42 \mathrm{~kg}$ a.i. $\mathrm{ha}^{-1}$ picloram, respectively, $\left.\operatorname{LSD}_{\alpha=0.05}=45.9\right)$. Picloram applications of $0.14,0.28$, and $0.42 \mathrm{~kg}$ a.i. $\mathrm{ha}^{-1}$ reduced total spotted knapweed densities to 49,10 , and 2 plants $\mathrm{m}^{-2}$ from 192 plants $\mathrm{m}^{-2}$ in the control $\left(\mathrm{LSD}_{\alpha=0.05}=53.9\right)$.

The effect of fertilizer on total spotted knapweed density was dependent upon the rate of picloram at site $2(\mathrm{p}<0.03)$. Without picloram, fertilizer applied at 132 $\mathrm{kg}$ a.i. ha ${ }^{-1}$ provided total spotted knapweed densities higher than the other fertilizer rates (Table 1). At all other picloram rates, spotted knapweed densities were similar.

At site 2, the effect of defoliation on total spotted knapweed density was dependent upon the rate of fertilizer applied ( $\mathrm{p}<$ $0.03)$. Without fertilizer, all defoliation treatments yielded similar total spotted knapweed density (Table 2). At $66 \mathrm{~kg} \mathrm{ha}^{-1}$, defoliation in all 3 seasons had higher spotted knapweed density than plots defoliated in the spring, summer, or fall. Alternating spring/fall grass defoliation yielded higher spotted knapweed densities than spring defoliation. All other treatments had similar spotted knapweed density at that fertilizer level. However, at 132 $\mathrm{kg} \mathrm{ha}^{-1}$ fertilzer, defoliating grass all 3 seasons had the highest total spotted knapweed density, but was similar to those plots defoliated each spring. Total spotted knapweed density was lowest in plots without defoliation, but was similar to plots defoliated alternating spring/fall at this fertilizer level. At $198 \mathrm{~kg} \mathrm{ha}^{-1}$ fertilizer, all defoliation treatments yielded similar total spotted knapweed density. Furthermore, total spotted knapweed density at this fertilizer level was similar to where fertilizer was not applied.

The effect of grass defoliation on the density of juvenile spotted knapweed plants was dependent upon the rate of picloram applied at site $2(\mathrm{p}<0.05)$. When no picloram was applied, spring
Table 1. Effect of picloram fertilizer combinations on total spotted knapweed density at site 1.

\begin{tabular}{|c|c|c|c|c|}
\hline \multirow[b]{2}{*}{ Picloram } & \multicolumn{4}{|c|}{ Fertilizer $\left(\mathrm{N}+\mathrm{P} \mathrm{kg} \mathrm{ha}{ }^{-1}\right)$} \\
\hline & 0 & 66 & 132 & 198 \\
\hline$\left(\mathrm{kg}\right.$ a.i. ha $\left.^{-1}\right)$ & \multicolumn{4}{|c|}{ 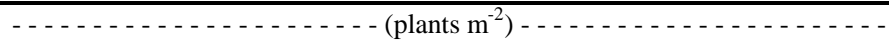 } \\
\hline 0.0 & 40 & 64 & 102 & 40 \\
\hline 0.14 & 3 & 21 & 10 & 8 \\
\hline 0.28 & 10 & 18 & 28 & 5 \\
\hline 0.42 & 8 & 7 & 5 & 10 \\
\hline \multicolumn{5}{|c|}{$\mathrm{LSD}_{\alpha=0.05}=25$} \\
\hline
\end{tabular}

Table 2. Effect of fertilizer and defoliation combinations on total spotted knapweed density at site 2.

\begin{tabular}{|c|c|c|c|c|c|c|}
\hline \multirow[b]{2}{*}{ Fertilizer } & \multicolumn{6}{|c|}{ Defoliation } \\
\hline & None & Spring & Summer & Fall & Alternate & $\mathrm{Sp}-\mathrm{Su}-\mathrm{Fa}$ \\
\hline$\left(\mathrm{N}+\mathrm{P} \mathrm{kg} \mathrm{ha}{ }^{-1}\right)$ & \multicolumn{6}{|c|}{$\ldots \ldots \ldots$ (plants $\left.\mathrm{m}^{2}\right) \ldots \ldots \ldots$} \\
\hline 0 & 18 & 13 & 23 & 18 & 13 & 7 \\
\hline 66 & 29 & 14 & 21 & 21 & 38 & 41 \\
\hline 132 & 13 & 43 & 35 & 38 & 29 & 59 \\
\hline 198 & 11 & 13 & 24 & 14 & 14 & 20 \\
\hline $\mathrm{LSD}_{\alpha=0.05}=19$ & & & & & & \\
\hline
\end{tabular}

defoliation resulted in the lowest juvenile spotted knapweed density, but was similar to alternating spring/fall defoliation (Table 3). Defoliation in the summer, fall, and all 3 seasons resulted in the highest densities of juvenile spotted knapweed plants. Picloram applied at $0.28 \mathrm{~kg}$ a.i. $\mathrm{ha}^{-1}$, had higher juvenile spotted knapweed densities when the plots were defoliated alternating spring/fall than when they were not defoliated. There were no differences in defoliation treatments when picloram was applied at $0.14 \mathrm{~kg}$ a.i. $\mathrm{ha}^{-1}$ and at $0.42 \mathrm{~kg}$ a.i. ha $^{-1}$.

Four years after treatment, picloram also interacted with fertilizer to affect juvenile spotted knapweed density at site 2 ( $\mathrm{p}<$ $0.001)$. In the picloram control, juvenile spotted knapweed density was higher in the 66 and $132 \mathrm{~kg} \mathrm{ha}^{-1}$ fertilizer treatments than the 0 and $198 \mathrm{~kg} \mathrm{ha}^{-1}$ treatments (Table 4). Juvenile spotted knapweed densities were higher in plots treated with $66 \mathrm{~kg} \mathrm{ha}^{-1}$ fertilizer than the fertilizer control when $0.14 \mathrm{~kg}$ a.i. $\mathrm{ha}^{-1}$ of picloram was applied. At the $0.28 \mathrm{~kg}$ a.i. $\mathrm{ha}^{-1}$ rate of picloram, juvenile spotted knapweed densities were higher in plots treated with $132 \mathrm{~kg} \mathrm{ha}^{-1}$ of fertilizer compared to 0 and $198 \mathrm{~kg} \mathrm{ha}^{-1}$. Juvenile spotted knapweed density was similar among all fertilizer treatments when picloram was applied at $0.42 \mathrm{~kg}$ a.i. ha ${ }^{-1}$.

\section{Biomass}

Biomass of spotted knapweed $(\mathrm{p}<0.001)$ and grass $(\mathrm{p}<0.001)$ were affected by picloram on site 1 , four years after treatment. Spotted knapweed biomass was the highest $\left(192 \mathrm{~kg} \mathrm{ha}^{-1}\right)$ when no picloram was applied $\left(\operatorname{LSD}_{\alpha=0.05}=54\right)$. Spotted knapweed biomass was 49,10 , and $2 \mathrm{~kg} \mathrm{ha}^{-1}$ at picloram rates of $0.14,0.28$, and $0.42 \mathrm{~kg}$ a.i. $\mathrm{ha}^{-1}$, respectively. Grass biomass was lowest $\left(2,250 \mathrm{~kg} \mathrm{ha}^{-1}\right)$ when no picloram was applied $\left(\operatorname{LSD}_{\alpha=0.05}=893\right)$. Plots treated with $0.14 \mathrm{~kg} \mathrm{ha}^{-1}$ of picloram had $5,060 \mathrm{~kg} \mathrm{ha}^{-1}$ of grass which was less than those treated with $0.28\left(5,960 \mathrm{~kg} \mathrm{ha}^{-1}\right)$ and $0.42 \mathrm{~kg}$ a.i. ha ${ }^{-1}\left(5,830 \mathrm{~kg} \mathrm{ha}^{-1}\right)$.

Biomass of grass was also affected by grass defoliation at site $1(\mathrm{p}<0.001)$. Grass biomass was lower in plots defoliated in all 3 seasons, $\left(3,940 \mathrm{~kg} \mathrm{ha}^{-1}\right)$, than in all other defoliation treatments $\left(\mathrm{LSD}_{\alpha=0.05}\right.$ $=561$ ). The control (no defoliation) had the highest grass biomass of $5,600 \mathrm{~kg} \mathrm{ha}^{-1}$,
Table 3. Effect of picloram and defoliation combinations on juvenile spotted knapweed density at site 2.

\begin{tabular}{lcccccc}
\hline \hline \multirow{2}{*}{ Fertilizer } & \multicolumn{6}{c}{ Defoliation } \\
\cline { 2 - 6 }$(\mathrm{kg}$ a.i. ha & None & Spring & Summer & Fall & Alternate & Sp-Su-Fa \\
0.0 & 34 & 16 & 54 & 46 & 26 & 52 \\
0.14 & 14 & 6 & 5 & 4 & 13 & 13 \\
0.28 & 4 & 9 & 13 & 11 & 21 & 17 \\
0.42 & 3 & 9 & 9 & 9 & 4 & 11 \\
$\mathrm{LSD}_{\alpha=0.05}=15$ & & & & & & \\
\hline
\end{tabular}


Table 4. Effect of picloram fertilizer combinations on juvenile spotted knapweed density site 2.

\begin{tabular}{|c|c|c|c|c|}
\hline \multirow[b]{2}{*}{ Picloram } & \multicolumn{4}{|c|}{ Fertilizer $\left(\mathrm{N}+\mathrm{P} \mathrm{kg} \mathrm{ha}^{-1}\right)$} \\
\hline & 0 & 66 & 132 & 198 \\
\hline$\left.\overline{(\mathrm{kg} \text { a.i. ha }}{ }^{-1}\right)$ & $\ldots$ & $-\ldots$ & $-\cdots$ & $-\ldots-$. \\
\hline 0.0 & 22 & 50 & 67 & 13 \\
\hline 0.14 & 3 & 18 & 8 & 8 \\
\hline 0.28 & 8 & 15 & 22 & 4 \\
\hline 0.42 & 8 & 7 & 5 & 10 \\
\hline $\operatorname{LSD}_{\alpha=0.05}=14$ & & & & \\
\hline
\end{tabular}

although it was similar to plots defoliated in the fall $\left(5,090 \mathrm{~kg} \mathrm{ha}^{-1}\right)$. There were $4,620,4,630$, and $4,530 \mathrm{~kg} \mathrm{ha}^{-1}$ of grass in the spring, summer, and altnerating spring/fall defoliations, respectively.

The effect of defoliation on spotted knapweed biomass was dependent upon the fertilizer treatment at site $2(\mathrm{p}<0.05)$. When fertilizer was not applied, all defoliation treatments were similar (Table 5). When fertilizer was applied at $66 \mathrm{~kg} \mathrm{ha}^{-1}$, defoliation in the spring resulted in the lowest spotted knapweed biomass, although it was similar to defoliation in the summer, fall, and the control. At 132 $\mathrm{kg} \mathrm{ha}^{-1}$ of fertilizer, defoliation in all 3 seasons resulted in spotted knapweed biomass higher than all other defoliation treatments. When fertilizer was applied at $180 \mathrm{~kg} \mathrm{ha}^{-1}$, all defoliation treatments yielded similar spotted knapweed biomass.

Table 5. Effect of fertilizer and defoliation combinations of total spotted knapweed biomass at site 2 .

\begin{tabular}{lllllcc}
\hline \hline \multirow{2}{*}{ Fertilizer } & \multicolumn{5}{c}{ Defoliation } \\
\cline { 2 - 6 } & None & Spring & Summer & Fall & Alternate & Sp-Su-Fa \\
\hline & -1 & 13 & 23 & 18 & 13 & 7 \\
66 & 18 & 14 & 21 & 21 & 38 & 41 \\
132 & 29 & 43 & 35 & 38 & 29 & 59 \\
198 & 13 & 13 & 24 & 14 & 14 & 20 \\
LSD $_{\alpha=0.05}=20$ & 11 & & & & & \\
\hline
\end{tabular}

The effect of defoliation on grass biomass was dependent upon the rate of picloram applied at site $2(\mathrm{p}<0.05)$. When picloram was not applied, defoliation in all 3 seasons yielded the lowest grass biomass, although it was similar to the effect of defoliation in the summer, spring, and alternating spring/fall (Table $6)$. The control, which was not defoliated, yielded the highest grass biomass and was similar to fall defoliation. When picloram was applied at $0.14 \mathrm{~kg}$ a.i. $\mathrm{ha}^{-1}$, alternating spring/fall defoliation resulted in the highest grass biomass. However it was similar to all treatments except summer defoliation and defoliation in all 3 seasons, which yielded lower biomass. At $0.28 \mathrm{~kg}$ a.i. ha ${ }^{-1}$, picloram applications interacted with alternating spring/fall grass defoliation to yield grass biomass lower than plots with no defoliation. When picloram was applied at $0.42 \mathrm{~kg}$ a.i. $\mathrm{ha}^{-1}$, alternating spring/fall defoliation resulted in the highest grass biomass. This treatment was similar to summer defoliation and defoliation in the fall only. Grass defoliation in the spring resulted in the lowest grass biomass, and was similar to the control and to defoliation in all 3 seasons.

\section{Cover}

At site 1 , there was a main effect of picloram on spotted knapweed cover 4 years after treatment $(p<0.001)$. Without picloram spotted knapweed cover was $26 \%$, which was higher than all 3 picloram treatments $\left(\mathrm{LSD}_{\alpha=0.05}=7.6\right)$. Picloram, applied at $0.14 \mathrm{~kg}$ a.i. ha ${ }^{-1}$, had spotted knapweed cover of $9 \%$ which was similar

to applications of $0.28 \mathrm{~kg}$ a.i. ha ${ }^{-1}(2 \%)$, but was higher than applications of 0.42 $\mathrm{kg}$ a.i. ha ${ }^{-1}$ which had spotted knapweed cover of less than $1 \%$. Picloram also had the only effect on grass cover at site $1(\mathrm{p}<$ $0.01)$. Picloram applications $(0.14,0.28$,

Table 6. Effect of picloram and defoliation combinations on grass biomass at site 2 .

\begin{tabular}{lllllll}
\hline \hline \multirow{2}{*}{ Fertilizer } & \multicolumn{5}{c}{ Defoliation } \\
\cline { 2 - 6 }$\left(\mathrm{kg} \mathrm{a.i.} \mathrm{ha}^{-1}\right)$ & None & Spring & Summer & Fall & Alternate & Sp-Su-Fa \\
0.0 & 4995 & 2793 & 3200 & 4103 & 2850 & 1982 \\
0.14 & 3165 & 2867 & 2531 & 4100 & 4161 & 2668 \\
0.28 & 5205 & 4556 & 4261 & 4713 & 3553 & 3838 \\
0.42 & 4315 & 3173 & 5710 & 5160 & 5990 & 3888 \\
LSD $_{\alpha=0.05}=1430$ & & & & & \\
\hline
\end{tabular}

and $0.42 \mathrm{~kg}$ a.i. ha ${ }^{-1}$ ) increased grass cover $(24,31$, and $30 \%)$ similarly over the control which was $15 \%\left(\operatorname{LSD}_{\alpha=0.05}=9\right)$.

Picloram had the only effect on spotted knapweed cover at site $2(\mathrm{p}<0.001)$. All picloram treatments $(0.14,0.28$, and 0.42 $\mathrm{kg}$ a.i. $\left.\mathrm{ha}^{-1}\right)$ provided lower spotted knapweed cover $(4,4$, and $2 \%)$ than the control which had a spotted knapweed cover of $25 \%\left(\mathrm{LSD}_{\alpha=0.05}=11\right)$.

Grass cover was affected by the interaction of picloram and fertilizer at site $2(\mathrm{p}<$ $0.04)$. When picloram was applied at 0.28 $\mathrm{kg}$ a.i. ha ${ }^{-1}$, a fertilizer rate of $66 \mathrm{~kg} \mathrm{ha}^{-1}$ produced the highest grass cover, however, it was similar to plots treated with picloram at $0.42 \mathrm{~kg}$ a.i. $\mathrm{ha}^{-1}$ and fertilizer applied at $132 \mathrm{~kg} \mathrm{ha}^{-1}$ (Table 7).

Grass cover at site 2 was also affected by defoliation treatments $(\mathrm{p}<0.01)$. Plots not defoliated produced the highest grass cover $(52 \%)$, although they were similar to those defoliated in the summer, which had grass cover of $47 \%\left(\operatorname{LSD}_{\alpha=0.05}=8\right)$. Grass cover in plots defoliated in all 3 seasons (33\%) was similar to grass cover in plots defoliated in alternate spring/fall (40\%).

Percent cover of litter at site 1 was affected by fertilizer rate ( $\mathrm{p}<0.002)$. Fertilizer applied at the highest rate yielded a higher litter cover $(43 \%)$ than applications of 66 and $132 \mathrm{~kg} \mathrm{ha}^{-1}$ (30 and $36 \%$ ), however, it was similar to the cover $(36 \%)$ in plots that received no fertilizer $\left(\mathrm{LSD}_{\alpha=0.05}=7.26\right)$.

The effect of defoliation on litter cover was dependent upon the picloram rate at site $1(\mathrm{p}<0.04)$. When picloram was not applied, plots that had not been defoliated had higher litter cover than those defoliated alternating spring/fall and all 3 seasons (Table 8). When picloram was applied at $0.14 \mathrm{~kg}$ a.i. $\mathrm{ha}^{-1}$, grass defoliation in all 3 seasons had lower litter cover than all other defoliation treatments. Rates of 0.14 , 0.28 , and $0.42 \mathrm{~kg}$ a.i. $\mathrm{ha}^{-1}$ that were not clipped provided higher litter cover than all other defoliation treatments. Also, when picloram was applied at $0.28 \mathrm{~kg}$ a.i. $\mathrm{ha}^{-1}$, defoliation in all 3 seasons produced lower litter cover than all other treatments except fall-only defoliation. 
Table 7. Effect of picloram and fertilizer $\left(\mathrm{kg} \mathrm{ha}^{-1}\right)$ combinations on percent grass cover at site 2 .

\begin{tabular}{|c|c|c|c|c|}
\hline \multirow[b]{2}{*}{ Picloram } & \multicolumn{4}{|c|}{ Fertilizer } \\
\hline & 0 & 66 & 132 & 198 \\
\hline$\left.\overline{(\mathrm{kg} \text { a.i. ha }}{ }^{-1}\right)$ & \multicolumn{4}{|c|}{ 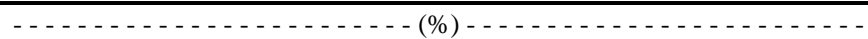 } \\
\hline 0.0 & 30 & 36 & 27 & 34 \\
\hline 0.14 & 37 & 40 & 48 & 38 \\
\hline 0.28 & 46 & 68 & 37 & 50 \\
\hline 0.42 & 46 & 41 & 55 & 44 \\
\hline $\operatorname{LSD}_{\alpha=0.05}$ & & & & \\
\hline
\end{tabular}

Table 8. Effect of picloram and defoliation combinations on percent litter cover at site 1.

\begin{tabular}{lllllll}
\hline \hline \multirow{2}{*}{ Fertilizer } & \multicolumn{5}{c}{ Defoliation } \\
\cline { 2 - 6 }$(\mathrm{kg}$ a.i. ha & None & Spring & Summer & Fall & Alternate & Sp-Su-Fa \\
0.0 & 34 & 33 & 28 & 30 & 20 & 18 \\
0.14 & 58 & 43 & 33 & 29 & 34 & 22 \\
0.28 & 63 & 38 & 35 & 33 & 40 & 24 \\
0.42 & 64 & 44 & 39 & 40 & 39 & 32 \\
LSD $_{\alpha=0.05=9}$ & & & & & \\
\hline
\end{tabular}

Percent cover of bare ground at site 1 was affected by defoliation treatments $(\mathrm{p}<$ $0.001)$. Plots that did not receive defoliation had lower bare-ground cover $(12 \%)$ than spring $(27 \%)$, summer $(32 \%)$, fall $(33 \%)$ and alternating spring/fall $(28 \%)$, while plots that were defoliated all 3 seasons had the highest bare ground cover $\left(41 \%, \operatorname{LSD}_{\alpha=0.05}=6\right)$. Bare-ground cover was also affected by the rate of fertilizer applied at site $1(\mathrm{p}<0.006)$. Bare-ground was higher when $66 \mathrm{~kg} \mathrm{ha}^{-1}$ of fertilizer was applied (37\%) than $0(28 \%), 132$ $(27 \%)$ or $198(23 \%) \mathrm{kg} \mathrm{ha}^{-1}$ fertilizer rates $\left(\mathrm{LSD}_{\alpha=0.05}=9\right)$.

Percent cover for both litter $(\mathrm{p}<0.05)$ and bare-ground $(\mathrm{p}<0.01)$ were affected only by defoliation at site 2 . Grass defoliation in the spring had higher litter cover $(46 \%)$ than none $(40 \%)$, summer $(39 \%)$, fall (40\%), Alternating spring/fall (41\%) and continuous $(40 \%)\left(\mathrm{LSD}_{\alpha=0.05}=5.0\right)$. Bare ground cover at site 2 was lower in plots that were not defoliated $(5 \%)$ than spring (9\%), summer (10\%), fall (9\%) and alternating spring/fall $(10 \%)\left(\mathrm{LSD}_{\alpha=0.05}=\right.$ $4)$. Defoliation in all 3 seasons resulted in the highest cover of bare-ground (16\%).

\section{Discussion}

We found a consistent trend of increased spotted knapweed densities at fertilizer applications of 66 and $132 \mathrm{~kg} \mathrm{ha}^{-1}$ over those observed at 0 or $198 \mathrm{~kg} \mathrm{ha}^{-1}$. We believe that spotted knapweed's rapid growth rate allowed it to capture available resources before neighboring desirable species (Sheley et al. 1993). Addition of
66 and $132 \mathrm{~kg} \mathrm{ha}^{-1}$ of fertilizer may have provided spotted knapweed juvenile plants nutrients needed for success, while providing no benefit to the grasses. When $198 \mathrm{~kg}$ $\mathrm{ha}^{-1}$ of fertilizer was applied, we speculate that the grasses were able to use the nutrients to their advantage.

Alternating spring/fall defoliation resulted in higher spotted knapweed density and biomass than annual spring or fall defoliation. Alternating spring/fall grazing is often recommended to improve range health because grasses are allowed to set seed and receive a rest period to allow seedling establishment (Rogler 1951, Johnson 1965, Frisna 1992). However, these recommendations do not take into account competition from a perennial weed. While alternating spring/fall defoliation provided the highest grass biomass at site 2, it also produced higher spotted knapweed density and biomass than annual spring or fall defoliations. We believe the grasses are placed at a competitive disadvantage when spring defoliation directly follows fall defoliation. Defoliation in the fall reduces the photosynthetic ability of the plant, which may result in the reduction of carbohydrate reserves (Deregibus et al. 1982). If the plants are defoliated the next spring, they may not have the carbohydrate reserve to recover. This potentially shifts the competitive balance to spotted knapweed, allowing it to establish new seedlings which may be able to out compete the suppressed grasses.

Fall defoliation alone appeared to be the most appropriate defoliation treatment for minimizing spotted knapweed reinvasion after weed control. It resulted in grass and spotted knapweed biomass that were similar to the undefoliated control. This was expected since grasses generally tolerate fall defoliation well. Because growth rates have slowed, removal of photosynthetic material does not draw large amounts of nutrients from the plants reserve (McLeen and Wikeem 1985). While fall-only defoliation may minimize spotted knapweed reinvasion, it may only be practical for a few livestock operations. As forage matures their nutritional quality decreases (Greene et al. 1987). Therefore, fall grazing may provide poor quality forage with low protein and digestability (Huston and Pinchak 1991).

One of the most significant results from this study was the difference between sites. Site 1 , with a residual understory of smooth bromegrass and timothy, was much more responsive to the picloram treatments than site 2 , which had a residual understory dominated by Kentucky bluegrass. The Kentucky bluegrass site was generally more affected by fertilizer and clipping treatments. Sheley and Jacobs (1997) reported that 2 years after application, picloram and fertilizer did not interact to affect grass yield or spotted knapweed density on either study site. In contrast, data from this study shows picloram and fertilizer interacted to decrease spotted knapweed density at site 2 . We believe the main effect of picloram faded to allow the more subtle effects of the fertilizer to be evident. The smooth bromegrass and timothy at site 1 were more responsive to applications of picloram and showed no effect from the fertilizer on spotted knapweed density, cover, or biomass even 4 years after application. We can conclude, therefore, that if a residual understory of strong, grazing tolerant grasses exists, reasonable grazing practices will not accelerate spotted knapweed reinvasion. However, if weaker grasses, such as Kentucky bluegrass, dominate the understory, avoiding improper grazing is critical to prevent reinvasion of spotted knapweed.

\section{Literature Cited}

Bedunah, D. and J. Carpenter. 1989. Plant community response following spotted knapweed (Centaurea maculosa L.) control on three elk winter ranges in western Montana. In: P.K. Fay and J.R. Lacey (eds.), Knapweed Symposium Proceedings, Montana Sate Univ., Bozeman, Mont.

Chicoine, E.S., P.K. Fay, and G.A. Neilsen. 1985. Predicting weed migration from soil and climate maps. Weed Sci. 34:57-61. 
Davis E.S. 1990. Spotted knapweed (Centaurea maculosa L.) seed longevity, chemical control, and seed morphology. M.S. Thesis, Montana State Univ., Bozeman, Mont.

Davis E.S., P. K. Fay, T.K. Chicoine, and C.A. Lacey. 1993. Persistence of spotted knapweed. Weed Sci. 41:57-61.

Deregibus,V.A., M.J. Trlica, and D.A. Jameson. 1982. Organic reserves in herbage plants: their relationship to grassland management. p.315-344. In: M.J. Recheigl (ed.) Handbook of agricultural productivity. Vol. I. Plant productivity. CRC Press. Bocona, Fla

Frisna, M.R. 1992. Elk habitat use within a rest-rotation grazing system. Rangelands 14:93-96.

Greene, L.W., W.E. Pinchak, and R.K. Heitschmidt. 1987. Seasonal dynamics of minerals in forages at the Texas experimental ranch. J. Range Manage. 40:502-506.

Griffith, D. and J. Lacey. 1989. Economics of knapweed control. In: P.K. Fay and J.R. Lacey (eds.), Knapweed Symposium Proceedings, Montana Sate Univ., Bozeman, Mont.

Hamaker, J.W., C.R. Youngson, and G.A. Goring. 1967. Predictions of the persistence and activity of Tordon herbicide in soils under field conditions. Down to Earth. 23:30-36.

Hart, R.H., M.C. Shoop, and M.M. Ashby. 1995. Nitrogen and atrazine on shortgrass: vegetation, cattle, and economic responses. J. Range Manage. 48:165-171.

Huston, J.E. and W.E. Pinchak. 1991. Range animal nutrition. In: R.K. Heitschmidt and J.W. Stuth (eds.) Grazing Management, an ecological perspective. Timber Press. Portland, Ore.
Jacobs, J.S. and R.L. Sheley. 1997. Relationship among Idaho fescue defoliation, soil water, and spotted knapweed emergence and growth. J. Range Manage. 50:258-262.

Johnson, W.M. 1965. Rotation, rest-rotation, and season-long grazing on a mountain range in Wyoming. USDA Forest Service. Res. Paper RM-41. 16p.

Lacey J.R., C.B. Marlow, and J.R. Lane. 1989. Influence of spotted knapweed (Centaurea maculosa) on surface runoff and sedimentation yield. Weed Technol. 3:627-631.

Maschinski, J. and T.G. Whitman. 1989. The continuum of plant responses to herbivory: the influence of plant association, nutrient availability, and timing. Amer. Natur. 134:1-19.

McLean, A. and S. Wikeem. 1985. Defoliation effects on three range grasses. Rangelands 7:61-63.

Meuggler, W.F. and W.L. Stewart. 1980. Grassland and Shrubland habitat types of Western Montana. USDA Forest Serv. Gen. Tech. Rep. INT-66.

Peterson, R.G. 1985. Design and analysis of experiments. Marcel Dekker, Inc. New York, N.Y.

Rogler, G.A. 1951. A twenty-five year comparison of continuous and rotation grazing in the Northern Plains. J. Range Manage. 4:35-41.

SAS Institute, Inc. 1990. SAS/STAT User's guide, Version 6, Fourth edition, Vol. 2, SAS Inst., Cary N.C.

Sheley, R.L. and J.S. Jacobs. 1997. Response of spotted knapweed and grass to picloram and fertilizer combinations. J. Range Manage. 50:263-267.
Sheley, R.L. and B.F. Roché. 1982. Rehabilitation of spotted knapweed infested rangeland in northwest Washington. Abstract. W. Soc. Weed Sci. Denver, Colo.

Sheley, R.L., J.S. Jacobs, and M.F. Carpinelli. 1998. Distribution, Biology, and Management of Diffuse Knapweed (Centaurea diffusa) and Spotted Knapweed (Centaurea maculosa). Weed Tech. 12:353362

Sheley, R.L. and L.L. Larson, and D.E. Johnson. 1993. Germination and root dynamics of Range Weeds and Forage Species Weed Tech. 7:243-237

Sheley, R.L, B.E. Olson, and L.L. Larson. 1997. Effect of weed seed rate and grass defoliation level on diffuse knapweed. J. Range Manage. 50:39-43.

Tyser, R.W. and C.H. Key. 1988. Spotted knapweed in a natural area fescue grassland: an ecological assessment. Northwest Sci. 62(4):151-166.

Watson, A.K. and A.J. Renney. 1974. The biology of Canadian weed.6. Centaurea mac ulosa and C. diffusa. Can. J. Plant Sci. 54:687-701. 